\title{
EXPERIENTIAL FUNCTION IN ENGLISH ZONE TEXTBOOK
}

\author{
Erwin Ashari \\ English Department \\ Riau Kepulauan University \\ erwinashariharianja83@gmail.com
}

\begin{abstract}
The aim of this study was to identify the experiential function aspect found in conversation text. They were Process, Participant and Circumtance. There were five chosen conversation texts then they were broken up into single clauses. They were taken from conversation text or clauses found in conversation text in student's English text book: English Zone. It was found that the conversation texts were categorized as simple text, because they were dominated by the simple cluase. The most dominant Process were Material Process (36.80\%). and Relational Process, meanwhile for Participant, the dominant were Attribution (28.22 \%), Attribute (19.78\%), Goal (17.16\%), Actor $(15.30 \%)$ and Carrier (14.93\%), the dominant Circumtances in conversation texts were Location Spatial (28.81\%), Manner (22.03\%), Location Temporal(20.34\%). Based on the findinds, it could be said that the conversation texts in those book refered to the natural conversation. there were three kinds of text found, they were Doing text, Saying text and Being text. The conversation texts were dominated by the Doing and Being texts. Doing text means that the texts were dominated by the Material Process, and Being text means that the texts were dominated by the Verbal Process
\end{abstract}

Keywords: Process, Participant, Circumtance, Being, Doing, Saying Texts

\section{INTRODUCTION}

Discourse analysis concerns the relationship between text and contexts in which it is used (McCarthy, 2000) and it is construal semiotics where semiotics refers to the relationships between signs and their users (Dijk, 1977). A construal semiotics indicates that a text determines and is determined by social context (Saragih, 2006). It shows that a text is influenced by the context. So does in domains of language use and and semiotics and language teaching, it is impossible to put them apart whenever it is used as an internalised system for communication (Kumral, 2013)

Discourse analysis covers text which refers to refers to any instance of language, in any medium, that makes sense to someone who knows the language as an object in its own right; two, focus on the text as an instrument for finding out about something else (Halliday \& Matthiessen, 2004). It is because when analyzing a language, analyzing grammar is not enough, but how this structure functions to make meaning in specific contexts is important too (Gee, 2011). This perception lead to the better understanding. 
When people speak or write, they produce text; and text is what listeners and readers engage with and interpret (Halliday \& Matthiessen, 2014), it explains that text is not only written language but also spoken language. Why is it so? Because spoken language can be textualized as textual function (Saragih, 2006). And textual function is one of the metafunction analysis (Halliday \& Matthiessen, 2014). .The used metafunction in langauge is in clause stage (Halliday \& Matthiessen, 2014). In clause, can be fond text and the meaning of the text is influence by the text (Saragih, 2006). In discour analysis it is prefer using clause to sentence, because it describes including not just sentences but any con-struction that is meaningful in the context in which it occurs as in pragmatics (Meyer, 2009).

Discourse analysis as a methodological approaches to the study of talk, both of which have far-reaching implications for our understanding of social interaction (Wooffitt, 2005). It means that discourse analysis cover the conversation where it is said that discourse analysis an approach to get the understanding of a conversation or interaction. Discourse is defined as a meaning that is realized in text (Saragih, 2006). It means, to express meaning, people use texts. Every text has own meaning that are influenced by the context. It shows that a language is complex and the meaning of the text is complex. Understanding the meaning of the text is also influenced by the background knowledge and background knowledge is one of the part of context. That why as Gurning says in (Ashari, 2015), discourse comprehension look likes an easy discussion, but actually it is hard to grasp. This phenomenon happens due to the influences of the context on text meaning changes.

The basic functions of language related to ecological and social environment comes into two, they are making sense of experience, and acting out social relationships as social creature (Halliday \& Matthiessen, 2004). Then sense of experience and social relationship realizes in metafunction. Metafunction of language is dealing with Systemic Function Linguistics views language as a resource for making meanings. It means that every single utterance of language is used to communicate meanings or messages. In this view the meanings relate to (1) the construal of the inner and outer world of experience, (2) the interaction with language, and (3) the organization of the inner and outer world of experience and the interaction with language. An utterance, therefore, has those three meanings: ideational or experiential meaning, interpersonal meaning and textual meaning. These three meanings are known as metafunction. The theory of metafunction is closed related with the other key concepts in systemic functional linguistics, such as the theory of system, the theory of register and context, the theory of stratum. And it is in compliance with his opinion of language, that is, language as social semiotic. Systemic functional grammar constructs a 
grammar for the purpose of text analysis to investigate how grammar is used as a means of making meaningThe process of exchange information or services can be realized on a group of text or a genre.

Metafunctionnis devided into three; Ideational Metafunction, Interpersonal Metafunction And Textual Metafunction.(Halliday \& Matthiessen, 2014). Every function has own analysis and domain analysis. Hasan argues in (O'Grady, 2010)that system networks exploring only the Ideational metafunction may be unable to distinguish all lexical items and suggests that lexical items such as ask/enquire, buy/purchase, smile/grin, cry/bawl realize identical sets of paradigmatic choices in the ideational metafunction.

Every human has experiences, and human construes his/her experience it is no matter spoken or written language though language (Halliday \& Matthiessen, 2014). This prosees is called as representation procees of experience. The human experience sometimes cannot be realized into text but it is ecceptable in social environment and it is called as logical function analysis of metafunction (Halliday \& Matthiessen, 2004), in another hand, an a social environment action which represents experience and can be realized into text is termed as experiential function (Saragih, 2006). So, it is clearly that ideational function is devided into two; logical function and experiential function.

In this article, it focuses on experiatial function as one of the idetional metafunction parts. As mentioned previously, the field of metafunction discussion on the level of clause as reperentation of tex. Reality in text or discourse is realized by the experience which is realized in the experiential function has three main elements; Process, Participant and Circumtance (Saragih, 2006). The Process, which is equivalent to activity or verb in traditional grammar, the Participants, which are A persons or things in the process, and the Circumstance, which is environment or surrounding of the activity involving the Participant (Saragih, 2006).

The main parts in clause is Process, and Participant (Halliday \& Matthiessen, 2004), while Circumtance is optionl (Saragih, 2006). Process function is devided into six type; Material, Behavioural, Mental, Verbal, Relational And Existential Process.

Table 1. Type of Process, ((Saragih, 2006)

\begin{tabular}{lll}
\hline Process type & Semantic Criteria & $\begin{array}{l}\text { Syntactic Criteria } \\
\text { and Example }\end{array}$ \\
\hline Material & $\begin{array}{l}\text { Occurring in outer side of human } \\
\text { beings (objective) } \\
\text { physical }\end{array}$ & $\begin{array}{l}\text { Unmarked: } \\
\text { V+ING } \\
\end{array}$ \\
\hline
\end{tabular}




\begin{tabular}{|c|c|c|}
\hline Behavioural & $\begin{array}{l}\text { physiological (on the body of human } \\
\text { being) }\end{array}$ & smile, laugh, sleep \\
\hline Mental & $\begin{array}{l}\text { Occurring in inner side of human } \\
\text { being (subjective) psychological one } \\
\text { human participant reversible } \\
\text { participants with other mental } \\
\text { process } \\
\text { - Cognition } \\
\text { - Affection } \\
\text { - Perception } \\
\text { - Desireability }\end{array}$ & $\begin{array}{l}\text { Unmarked: } \\
\text { not in V+Ing } \\
\text { that-clause (projection) } \\
\text { know, realize, remember.. } \\
\text {-like, love, hate, enjoy... } \\
\text {-see, feel, hear... } \\
\text { want, wish, intend }\end{array}$ \\
\hline Verbal & $\begin{array}{l}\text { Both human and inhuman } \\
\text { participants } \\
\text { information }\end{array}$ & $\begin{array}{l}\text { projecting (that-clause) } \\
\text { say, tell, ask }\end{array}$ \\
\hline Relational & $\begin{array}{l}\text { Occurring both inside and outside } \\
\text { human being both human and } \\
\text { inhuman participants } \\
\text { - Identification } \\
\text { - Attribution } \\
\text { - Possession }\end{array}$ & $\begin{array}{l}\mathrm{N} \Lambda \mathrm{BE} \Lambda \mathrm{N} \\
\mathrm{N} \Lambda \mathrm{BE} \Lambda \mathrm{ADJ} \\
\mathrm{N} \Lambda \mathrm{BE} \Lambda \mathrm{ADV} \\
\mathrm{BE} \text { (is, are, was..) become, } \\
\text { sound, look, play is, are, was }\end{array}$ \\
\hline Existential & Existence of entity & $\begin{array}{l}\text { There } \Lambda \mathrm{BE} . . \\
\text { There is a car in the park. } \\
\mathrm{BE} \text {, come, go }\end{array}$ \\
\hline
\end{tabular}

Semantic and Syntatic criteria distinguish type of Process from the others. The semantic criteria refer to the natural of the Process itself related to the natural social life. Meanwhile syntactic criteria refer to the how to combine those Process into grammatical aspects, such as the the position and joing words in clause pattern. Syntatic criteria of Material Process is Unmarked in V-Ing. Unmarked means is usual and acceptable. Usual means, its occuracy of possibility is in small number. Example; run walk, write do, they are unmarked or usual in $\mathrm{V}$-ing form, meanwhile for the examples of Behavioural and Mental Process, they are marked or unusual but in some cases they are unacceptable due to semantic. So, the both criteria make them different each other. Those Process, are ometime shre the characteristis, but it does not a matter, because it also will be differed by the semantics criteria as in natural life or social interaction. There are actually three primary process ant the three primary process share the syntactic critery. As in figure 1. 


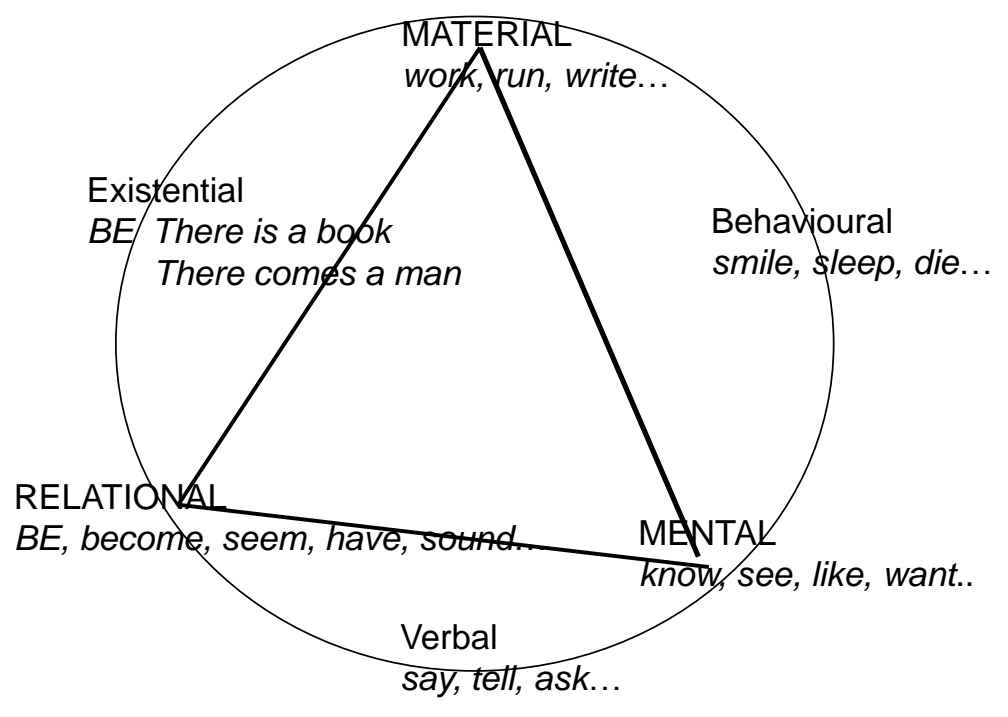

Figure 1. The Types of Process in Spectrum(Saragih, 2006)

Second primary element of Experiential Function is Participant. The Participant itself is lebel by the type of the Process. it can bee seen in the following table;

Table 2. Process and Participant (Saragih, 2006)

\begin{tabular}{lll}
\hline Types of Process & Participant I & Participant II \\
\hline Material & Actor & Goal \\
Mental & Senser & Phenomenon \\
Relational & & \\
(a) Identification & Token & Value \\
(b) Attribution & Carrier & Attribute \\
(c) Possession & Possessor & Possessed \\
Behavioral & Behaver & -- \\
Verbal & Sayer & Verbiage \\
Existential & -- & Existent \\
\hline
\end{tabular}

Circumstances refer to environments or surroundings of where activities involving the Participants occur. The environments and may refer to location, manner, matters, accompaniment and others. The circumstantial elements of clause divide into nine main categories (Saragih, 2006). 
Table 3. Circumtance

\begin{tabular}{|c|c|c|c|}
\hline $\begin{array}{l}\text { Types of } \\
\text { Circumstance }\end{array}$ & Subcategories & Probe & Examples of Realization \\
\hline \multirow[t]{2}{*}{ 1. Extent } & $\begin{array}{l}\text { temporal } \\
\text { (duration) }\end{array}$ & for how long? & $\begin{array}{l}\text { for three hours } \\
\text { every three hours }\end{array}$ \\
\hline & $\begin{array}{l}\text { spatial } \\
\text { (distance) }\end{array}$ & how far? & for six miles \\
\hline \multirow[t]{2}{*}{ 2. Location } & $\begin{array}{l}\text { temporal } \\
\text { (time) }\end{array}$ & when? & $\begin{array}{l}\text { in September } \\
\text { before tea }\end{array}$ \\
\hline & spatial (place) & where? & $\begin{array}{l}\text { in the market } \\
\text { in Paris } \\
\text { here }\end{array}$ \\
\hline 3. Manner & - & how? & $\begin{array}{l}\text { Quickly } \\
\text { as fast as possible }\end{array}$ \\
\hline 4. Cause & - & why? & $\begin{array}{l}\text { because of you } \\
\text { for better results }\end{array}$ \\
\hline 5. Contingency & - & $\begin{array}{l}\text { in what } \\
\text { circumstances? }\end{array}$ & $\begin{array}{l}\text { in the event of rain } \\
\text { in spite of the rain } \\
\text { in the absence of proof }\end{array}$ \\
\hline 6. Accompaniment & - & together with? & $\begin{array}{l}\text { with(out) his friends } \\
\text { instead of them }\end{array}$ \\
\hline 7. Role & - & what as? & $\begin{array}{l}\text { as a concerned parent } \\
\text { (smashed) into pieces }\end{array}$ \\
\hline 8. Matter & - & what about? & $\begin{array}{l}\text { about this } \\
\text { with reference to that }\end{array}$ \\
\hline 9. Angle & - & says who? & $\begin{array}{l}\text { according to the Shorter } \\
\text { Oxford }\end{array}$ \\
\hline
\end{tabular}

Experiential function takes part in conversation text as the representative of oral conversiation. It means that conversation text is oral conversation written form. Conversation involved two directions, conversation analysis is not about the number of the addreser and adresee. Eventhoug they are in a goup, but the addreser must be one direction and others act as addresee. Every utterence that is uttered it is called as move (Saragih, 2006) it is similar to (Wooffitt, 2005) statement that conversation examines language as social action. So, it is clear that conversation analysis refers to the action or utterence not the numbers. It similar to (Zhang, 2008) states that to share experience or knowledge can be conducted through a 
conversation as its purpose to exchange information, establish and maintain the relationship between people.

Education refers to Learn in an organized, progressive, and systematic manner according to some generally accepted principles about what people ought to know (Halliday, 2007). In education has type on learning a subject, include language subject material such as English subject. Beside time schadule which referes to the progressive and systematic mannar to meet the purpose by the school elements or educational organitation, principle of approuch used must be a considaration too. This approuch inlude textbook, which takes a role as a mean of a formal manual instruction in a specific subject. (Ashari, 2015). The textbook its self can help teacher to run his/her nine roles in they are as a controller, an assessor, an organizer/manager, a prompter/motivator, participant, a resource/informer, a facilitator, a demonstrator, and as a guide (Rindu \& Ariyanti, 2017). Beside it, a teacher prefers do recasts and explicit correction on corrective feedback types, either experienced and novice teachers on classroom interaction (Öztürk, 2016) and the students prefer on explicit corrective feedback was based on the reason that it provided answer and explanation on the correct version (Fitriana, Suhatmady, \& Setiawan, 2016).

In textbook, there are some conversation text found. Talking about the conversation, it relates to the experiential function as mentioned above. It means that experiential function take a part in convesation, both oral and written form. As Lepschy states in (Rickheit \& Strohner, 2008), conversation means verbal and non-verbal human acts aimed at mutual understanding. Understanding here must be understood in the broad sense of establishing common meanings for practical goals. It means that the most important is about the comprehending meaning. The recent language education is focusing on communicative competence. It means in education, the students are expected to be able to understand and comprehend conversation in the textbook. They conduct conversation to share the knowledge, opinion, feel, experience, suggestion etc, through the speech function. Futheremore present study confirmed the claim that while language is a virtual system with choices, text is a real system where choices of a language are realized through certain patterns (Kurtu, 2012), it means that conversation text related to the experiential function analysis.

\section{METHODOLOGY}

A research needs a resech design where design is defined as a writer's plan of how to proceed (Bogdan \& Biklen, 1994). So, this research uses qualitative reseach, specically it applies a descriptive research design. It is because A research should be limited to 
frequently used forms. surveys and experiments in quantitative research; narrative research, phenomenology, grounded theory, ethnography, and case studies in qualitative research; and convergent, explanatory sequential, and exploratory sequential designs in mixed methods research (Creswell, 2014). A descriptive research design will be applied in this study where descriptive research involves collecting data in order to answer questions concerning the current status of the object of the study (Gay, Millls, \& Airasian, 2012).

Descriptive design simply describes what is going on what data shows; because it focuses on the natural characteristics of the data. In the other word, how a theory works in different phenomena. The purpose of using the descriptive design is simply because through this design, the fact of the area of interests is able to gather and to describe systematically. And this research is designed with single case system, where it will be By using this method the data will be analyzed, and the result of the research is the description of congruent and metaphor coding in conversation texts of the students' textbook.

Data sources means for seeking convergence across qualitative and quantitative methods (Creswell, 2014). Since, it is qualitative research, so data source were taken from conversation text or clauses found in conversation text in student's English text book: English Zone written by Eka Mulya Astuti, 2010, entitled; English Zone for Senior High SCHOOL students Year XI, published by Erlangga in Jakarta. There were five chosen conversation texts then they were broken up into single clauses. The whole single clauses were made as the data of this research. The conversation texts that were chosen about "Self Introducing" "Giving Opinion", "Talking About Animal Treatment”, "Talking About Smoking”, Talking About Adventure Story", and "Talking About Pamphlet".

The technique of collecting data is a step to gather the data, and every research has different way, it can be including include setting the boundaries for the study, collecting information through unstructured or semi structured observations and interviews, documents, and visual materials, as well as establishing the protocol for recording information (Creswell, 2014). The procedures of collecting data in this reseach were retyping the conversation texts, breaking the clauses of conversation texts to be made as data and then printing out the data. Then data were analyzed by identifying conversation texts, the Process, participant and Circumtance of the clauses of the conversation texts then finding or computing the percentages based on the types of Process, participant and Circumtance, then describing coding and findings, then reasoning or elaborating why the dominant type was used in conversation texts. As (M.Given, 2008) states that to ensure the study's trustworthiness 
entails many of the strategies used in qualitative research may include; Credibility, Transferability, Dependability, and Conformability.

\section{FINDINGS AND DISCUSSION}

There were 148 clauses in all selected conversation texts of students' English textbook: English Zones. There were 121 simple clauses and 27 complex clauses, so the total clauses were 148 clauses. To make it clear then it was tabulated into the following table;

Table 1. Type of Clause

\begin{tabular}{|c|c|c|c|c|}
\hline No & Conversation Text & $\begin{array}{l}\text { Simple } \\
\text { Clauses }\end{array}$ & $\begin{array}{l}\text { Complex } \\
\text { Clauses }\end{array}$ & Total \\
\hline $\mathrm{a}$ & "Introduction" & 14 & 1 & 15 \\
\hline $\mathrm{b}$ & "Giving Opinion" & 12 & 2 & 14 \\
\hline $\mathrm{c}$ & $\begin{array}{l}\text { "Talking About Animal } \\
\text { Treatment" }\end{array}$ & 9 & 3 & 12 \\
\hline $\mathrm{d}$ & "Talking About Smoking" & 15 & 3 & 18 \\
\hline $\mathrm{e}$ & "Talking About Adventure Story" & 49 & 8 & 57 \\
\hline $\mathrm{f}$ & "Talking About Pamphlet" & 22 & 10 & 32 \\
\hline TO & & 121 & 27 & 148 \\
\hline
\end{tabular}

Based on the table 1. it was known that the dominant type of the text was simple clause, it reached 121 clauses $(81,75 \%)$ meanwhile complex clause was 27 clauses $(18,25)$, it showed that the all texts were categorized as simple text. Among six conversation texts, it showed that 'Introducing' conversation text was the most simple due to its complex clause numbers. The number of a process in a cluse could be different, it depended on the kind of the clause, such as in simple clause which had only one Process, because to be called as clause, it had one Process, meanwhile in complex clause, it was possible to have several Processes, it was because in complex clause, main clause and suborninate clause were found, and in Systemic Functional Grammar Approcah (Saragih, 2006) they are called as embeded clause. Embeded clause means a clause in a clause, they can be found in participant or circumtance.

After having the numbers, then the clauses were identified based on their categorized. As mantion previously, that there were three main parts of a clause based on Systematic Functional Grammar aproach; Process, Participats, and Circumtance. 
Moreover, it could be described the type of Proceses found in conversation text of students' English textbook they were Material process, Mental process, Relational process, behavioral process, Verbal process and Existential process, to make it clear then it was tabulated into the following table.

Table 2. Number of Process

\begin{tabular}{|c|c|c|c|c|c|c|c|c|c|}
\hline No & Process & $\begin{array}{c}\text { Text } \\
a\end{array}$ & $\begin{array}{c}\text { Text } \\
b\end{array}$ & $\begin{array}{c}\text { Text } \\
c\end{array}$ & $\begin{array}{c}\text { Text } \\
d\end{array}$ & $\begin{array}{c}\text { Text } \\
e\end{array}$ & $\begin{array}{c}\text { Text } \\
f\end{array}$ & $\begin{array}{c}\text { Tota } \\
l\end{array}$ & $\begin{array}{c}\text { Percenta } \\
\text { ge }\end{array}$ \\
\hline 1 & Material & 5 & 2 & 6 & 9 & 25 & 13 & 60 & $36.80 \%$ \\
\hline 2 & Mental & 4 & 5 & 3 & 3 & 12 & 11 & 38 & $23.32 \%$ \\
\hline \multirow[t]{4}{*}{3} & Relational & & & & & & & & \\
\hline & a. Identification & & & 1 & & 1 & & 2 & $1.23 \%$ \\
\hline & b. Attribution & 6 & 6 & 4 & 5 & 14 & 11 & 46 & $28.22 \%$ \\
\hline & c. Possession & & & & 1 & & 3 & 4 & $2.45 \%$ \\
\hline 4 & Behavioural & & 1 & & & 1 & & 2 & $1.23 \%$ \\
\hline 5 & Verbal & 1 & & 1 & 2 & 5 & & 9 & $5.52 \%$ \\
\hline 6 & Existential & & & & 1 & 1 & & 2 & $1.23 \%$ \\
\hline & & & Total & & & & & 163 & $100 \%$ \\
\hline
\end{tabular}

Based on the table. 2, it was found that the most dominant Process in conversation text were Material Process $(\mathbf{3 6 . 8 0} \%)$ ). and Relational; Attribution Process $(\mathbf{2 8 . 2 2} \%)$ was in the second place. Behavioural and Existential Process were the lowest number (1.23 \%). Since the number of Material Process was the highest, it can be said that the conversation text refered to the Being text.

Table 3. Number of Participant I, II \& III

\begin{tabular}{llcccccccc}
\hline No & & Text & Text & Text & Text & Text & Text & Total & Percentage \\
& & $\boldsymbol{a}$ & $\boldsymbol{b}$ & $\boldsymbol{c}$ & $\boldsymbol{d}$ & $\boldsymbol{e}$ & $\boldsymbol{f}$ & & \\
\hline 1 & Actor & 3 & 2 & 4 & 9 & 15 & 8 & $\mathbf{4 1}$ & $\mathbf{1 5 . 3 0 \%}$ \\
2 & Senser & 1 & 5 & 3 & 3 & 1 & 9 & $\mathbf{2 2}$ & $\mathbf{8 . 2 1 \%}$ \\
3 & Token & & & 1 & & 1 & & $\mathbf{2}$ & $\mathbf{0 . 7 5 \%}$ \\
4 & Carrier & 6 & 1 & 4 & 5 & 14 & 10 & $\mathbf{4 0}$ & $\mathbf{1 4 . 9 3 \%}$
\end{tabular}




\begin{tabular}{|c|c|c|c|c|c|c|c|c|c|}
\hline 5 & Possessor & & & & 1 & & 3 & 4 & $1.49 \%$ \\
\hline 6 & Behaver & & 1 & & & 1 & & 2 & $0.75 \%$ \\
\hline 7 & Sayer & 1 & & 1 & 2 & 4 & & 8 & $2.99 \%$ \\
\hline 8 & Goal & 3 & 3 & 5 & 5 & 20 & 10 & 46 & $17.16 \%$ \\
\hline 9 & Phenomenon & 2 & 3 & 3 & 3 & 8 & 10 & 29 & $10.82 \%$ \\
\hline 10 & Value & & & & & 1 & & 1 & $0.37 \%$ \\
\hline 11 & Attribute & 6 & 7 & 4 & 5 & 14 & 17 & 53 & $19.78 \%$ \\
\hline 12 & Possessed & & & & 1 & & 3 & 4 & $1.49 \%$ \\
\hline 13 & Verbiage & 1 & & & 2 & 2 & & 5 & $1.87 \%$ \\
\hline 14 & Existent & & & & 1 & 1 & & 2 & $0.75 \%$ \\
\hline 15 & Recipient & & & 1 & & 3 & 1 & 5 & $1.87 \%$ \\
\hline 16 & Client & & & & 1 & 1 & & 2 & $0.75 \%$ \\
\hline 17 & Receiver & & & & & 1 & & 1 & $0.37 \%$ \\
\hline 18 & Beneficiary & & 1 & & & 3 & 3 & 7 & $2.61 \%$ \\
\hline 19 & Range & & & & & 1 & & 1 & $0.37 \%$ \\
\hline
\end{tabular}

Based on the table. 3, it was found that the most dominant Participants in conversation text were Attribute $(\mathbf{1 9 . 7 8 \%})$, Goal (17.16\%), Actor $(\mathbf{1 5 . 3 0 \%})$ and Carrier (14.93\%). Meanwhile for thelowest were Behaver Existent Value, Client (0.75\%), Receiver, and Range( $\mathbf{0 . 3 7 \%})$.

Table 4. Number olf Circumtance

\begin{tabular}{|c|c|c|c|c|c|c|c|c|c|}
\hline No & Circumtance & $\begin{array}{c}\text { Text } \\
\qquad a\end{array}$ & $\begin{array}{c}\text { Text } \\
\quad b\end{array}$ & $\begin{array}{c}\text { Text } \\
c\end{array}$ & $\begin{array}{c}\text { Text } \\
\quad d\end{array}$ & $\begin{array}{c}\text { Text } \\
e\end{array}$ & $\begin{array}{c}\text { Text } \\
f\end{array}$ & Total & Percentage \\
\hline 1 & Extent temporal & & & & & 2 & & 2 & $3.39 \%$ \\
\hline 2 & Extent spatial & 1 & & & & & 1 & 2 & $3.39 \%$ \\
\hline \multirow[t]{2}{*}{3} & Location & & 1 & & 1 & 8 & 2 & 12 & $20.34 \%$ \\
\hline & Temporal & & & & & & & & \\
\hline 4 & Location Spatial & 1 & & 1 & & 13 & 2 & 17 & $28.81 \%$ \\
\hline 5 & Manner & & & 1 & 4 & 4 & 4 & 13 & $22.03 \%$ \\
\hline 6 & Cause & & & & & & 1 & 1 & $1.69 \%$ \\
\hline 7 & Contingency & & & 1 & & 1 & 2 & 4 & $6.78 \%$ \\
\hline 8 & Role & & & & & & & & \\
\hline
\end{tabular}




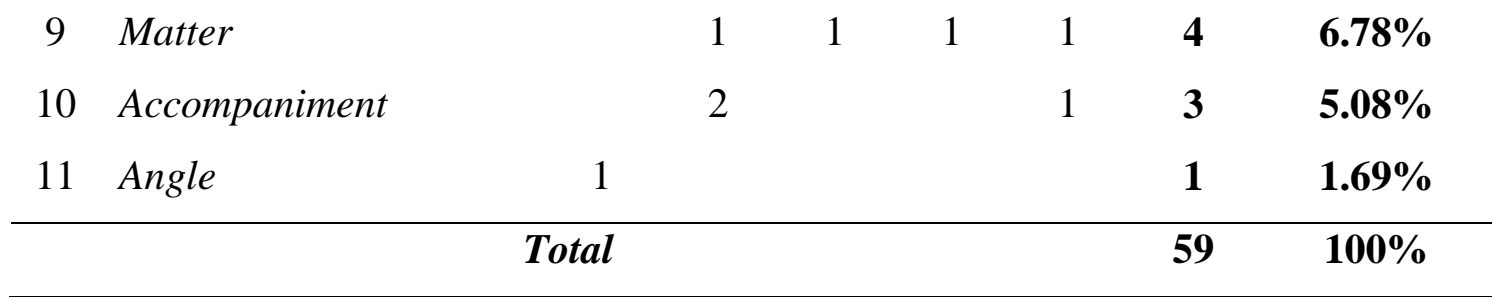

Based on the table. 4, it was found that the most dominant Circumtances in conversation texts were Location Spatial (28.81\%), Manner (22.03\%), Location Temporal(20.34\%), meanwhile for the lowest were Cause Angle (1.69\%)

Basicly, coversation text is similar to direct conversation, and they are just differed by the form, coversation text is presented by the written form and direct conversation is presented by spoken language. even though sometimes the reader in conversation text miss the context but it does matter for several conversation text which written in conplete clauses, at least the reader can follow or understand the context,

The use of conversation text during learning process is one of the best ways to stimulate students' speaking skill beside practice. But is it very important to know the characteristics of the conversation itself, so that it can be related to the writing skill, especially writing conversation itself. in conversation text, as mentioned above, Process takes as the main part of a clause, it indicates that the first analysis of a clause is begun from the Process identifiction and dominant kind of Process lead to name of the text itself (Saragih, 2006).

There were 148 clauses in all selected conversation texts of students' English textbook: English Zones. There were 121 simple clauses and 27 complex clauses.based on the number of the clauses, texts are categorized as simple text. It is suitable, since the textbook is presented to senior high school. Improving students' language comprehension on complex clause need too but can be as a phenomenon for students when the miss the context. The complex clause is more suitable to the direct conversation rather than in written text.

After having finding, it can be concluded that there were three kinds of text found, they were Doing text, Saying text and Being text. The conversation texts were dominated by the Doing and Being texts. In Doing Text, the dominan kind of text must be Material Process. Eventhough it was the main kind, it did not mean that the rest Pocesses were absent, it just showed that the conversation refered to the physical human or non human being, in another word Material Process needed an object. Doing text leads the text to the action or real activity. In another word, Doing text refers to the talking about activity or doing an activity. Saying text, the dominant kind must be Verbal Process, meanwhile Being text means 
that the dominant Process is Relational Process. The various number of the Process in English Zone book showed that the conversation texts refered to the natural conversation, because in natural conversation a conversation text could not be predicted. In natural conversation it often happen switch Process used to get the aim eventhouh in the in the same text. Based on the result, it can be said that actually the conversation text on those books were natural conversation because there were unique realtionship.

\section{REFERENCES}

Ashari, E. (2015). Patterns of Coding in Conversation Texts of the English Zone. AngloSaxon, 6(8), 39-46. Retrieved from http://journal.unrika.ac.id/index.php/jurnalanglosaxon/article/view/357

Bogdan, R. C., \& Biklen, S. K. (1994). Qualitative Research in Education: an introduction to the theory and methods. Porto: Porto Editora.

Creswell, J. W. (2014). Research Design: Qualitative, Quantitative, and Mixed Methods Approaches. Research design Qualitative quantitative and mixed methods approaches. http://doi.org/10.1007/s13398-014-0173-7.2

Dijk, T. A. Van. (1977). Text and Context. London: Longman Linguistics Library.

Fitriana, R., Suhatmady, B., \& Setiawan, I. (2016). Students' Preferences toward Corrective Feedbacks on Students' Oral Production. Script Journal: Journal of Linguistic and English Teaching, 1(1), 46-60.

Gay, L. R., Millls, G. E., \& Airasian, P. (2012). Educational Research Competencies for Analysis and Application. Pearson Education (Vol. 1). http://doi.org/10.1017/CBO9781107415324.004

Gee, J. P. (2011). An Introduction to Discourse Analysis; Theory and method (3rd ed.). London: Routledge.

Halliday, M. A. . (2007). Language and Education. (J. J. Webster, Ed.), The collected Works of M.A.K. Halliday. (9th ed.). London: Great Britain by Biddies Ltd.,.

Halliday, M. A. K., \& Matthiessen, C. M. I. . (2004). An Introduction to Functional Grammar. An introduction to functional grammar (3rd ed.). London: Arnold. http://doi.org/10.4324/9780203431269

Halliday, M. A. K., \& Matthiessen, C. M. I. M. (2014). Halliday's Introduction to Functional Grammar (4th ed.). Abingdon: Routledge.

Kumral, N. (2013). Semiotic analysis of textual communication in Snow by Julia Alvarez. Journal of Language and Linguistics Studies, 9(2), 31-44.

Kurtu, K. (2012). An Inquiry into Connectives and Their Use in Written Discourse. The Journal of Language and Linguistic Studies, 8(1), 110-131.

M.Given, L. (2008). Document analysis. In The Sage Encyclopedia of Qualitative Research Methods (1st \& 2nd ed., p. 1014). SAGE Publications Ltd. http://doi.org/10.4135/9781412963909

McCarthy, M. (2000). Discourse Analysis for Language Teachers (10th ed.). London: Cambridge University Press. http://doi.org/10.2307/3587181

Meyer, C. F. (2009). Introducing English Linguistics. Cambridge: Cambridge University Press. http://doi.org/10.1017/CBO9780511757822

O'Grady, G. (2010). A Grammar of Spoken English Discourse. London: Continuum International Publishing Group. 
Öztürk, G. (2016). An investigation on the use of oral corrective feedback in Turkish EFL classrooms. Journal of Language and Linguistics Studies, 12(2), 22-37.

Rickheit, G., \& Strohner, H. (2008). Handbook of Communication Competence. (K. Knapp \& G. Antos, Eds.) (Volume 1). New York: Walter de Gruyter GmbH \& Co.

Rindu, I., \& Ariyanti. (2017). Teacher's Role in Managing the Class during Teaching and Learning Process. Script Journal: Journal of Linguistic and English Teaching, 2(1), 83100. http://doi.org/http://dx.doi.org/10.24903/sj.v2i1.77

Saragih, A. (2006). Discourse Analysis. Medan: Universitas Negeri Medan.

Wooffitt, R. (2005). Conversation Analysis and Discourse Analysis. London: SAGE Publications Ltd. Retrieved from http://katalog.suub.unibremen.de/DB=1/LNG=DU/CMD?ACT $=S R C H A \& I K T=8000 \& T R M=77336744 * \mathrm{H} 1$ State and University Library Bremen $\% 5 \mathrm{Ct} \% 5 \mathrm{Ct} \% 5 \mathrm{Ct} \% 5 \mathrm{Ct} \mathrm{H} 2$ - a sow 065/975 H1 State and University Library Bremen $\% 5 \mathrm{Ct} \% 5 \mathrm{Ct} \% 5 \mathrm{Ct} \% 5 \mathrm{Ct} \mathrm{H} 2$ - h sow 065/975a H1 State a

Zhang, Z. (2008). Discourse Analysis and Cultivation of Conversational Competence in English Class. International Education Studies, 1(3), 60-62. 